\title{
Scalable 9-Step Synthesis of the Splicing Modulator NVS-SM2
}

\author{
Hussein Abou-Hamdan, ${ }^{\dagger+}$ Laurent Désaubry ${ }^{\dagger *}$ \\ ${ }^{\dagger}$ Laboratory of Therapeutic Innovation (UMR 7200), University of Strasbourg-CNRS, Faculty of Pharmacy, 67401, Illkirch, \\ France \\ *Laboratory of Biomolecules (UMR7203), Sorbonne University-CNRS, 4 place Jussieu, 75005 Paris, France \\ Supporting Information
}

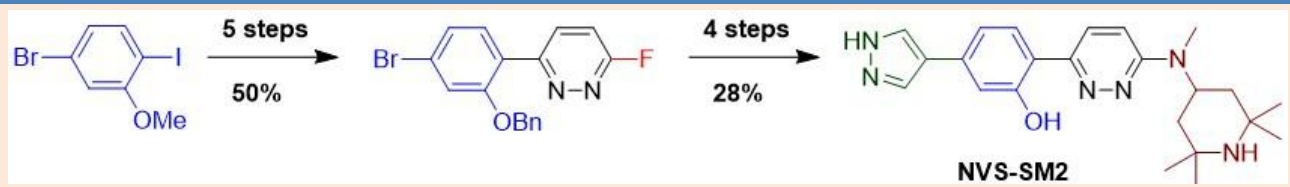

ABSTRACT: NVS-SM2, the first activator of pre-mRNA splicing, displays remarkable pharmacological in vivo activities in models of spinal muscular atrophy. Herein we describe an improved approach to the synthesis of this compound, which features a convenient introduction of sterically encumbered amine moiety onto a fluoropyridazine intermediate.

In 2015, Novartis scientists reported the discovery of NVSSM2 (1, Scheme 1), the first activator of pre-mRNA splicing. ${ }^{1}$ This orally active small molecule doubled life-span in a majority of treated mice in a model of spinal muscular atrophy (SMA). SMA is a major genetic cause of infant mortality caused by a mutation of the gene SMN that is essential to premRNA splicing. The pharmacological investigation of $\mathbf{1}$ in SMA and other diseases is highly hindered by the availability of this compound. Indeed its preparation on an $8 \mathrm{mg}$ scale has only been reported in one patent by Novartis' scientists. ${ }^{2}$ The caveat in this synthesis lies in the deprotection of the phenol and the introduction of sterically hindered amine that respec- tively occurred with a 13 and $55 \%$ yield, and also with the Suzuki-Miyaura coupling of highly functionalized aryl and heteroaryl moieties, the yield of which was not reported (Scheme 1). In this communication, the execution of a 9-step, scalable synthesis of $\mathbf{1}$ is presented.

To overcome the limitation of the original synthesis of NVSSM2, we explored several routes and we finally envisioned to protect the phenol as a benzyloxy and to introduce the congested amine onto a reactive fluoropyridazine. We considered also to assembly the aryl and heteroclic moieties Suzuki coupling under optimized reactions (Scheme 2).

\section{Scheme 1. Novartis Synthesis of NVS-SM2}

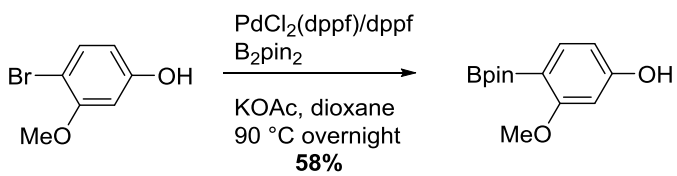
$8 \%$<smiles>Cc1ccc(Cl)nn1</smiles><smiles>CNC1CC(C)(C)NC(C)(C)C1</smiles><smiles>CN(c1ccc(Cl)nn1)C1CC(C)(C)NC(C)(C)C1</smiles><smiles>C1CC1</smiles>
$100{ }^{\circ} \mathrm{C}, \mathrm{MW} 1 \mathrm{~h}$
yield not reported<smiles>COc1cn[nH]c1</smiles><smiles>CN(c1ccccc1)c1ccc(-c2ccc(-c3cn[nH]c3)cc2O)nn1</smiles><smiles>COc1cc(-c2cn[nH]c2)ccc1-c1ccc(NC2CC(C)(C)NC(C)(C)C2)nn1</smiles>

$\mathrm{Pd}_{2}(\mathrm{dba})_{3} / \mathrm{S}-\mathrm{Phos}$ $\mathrm{K}_{3} \mathrm{PO}_{4}$, dioxane $/ \mathrm{H}_{2} \mathrm{O}$ $100{ }^{\circ} \mathrm{C}, \mathrm{MW} 1 \mathrm{~h}$ yield not reported $\mathrm{TfO}$<smiles>COc1cc(O)ccc1-c1ccc(N(C)C2CC(C)(C)NC(C)(C)C2)nn1</smiles> 

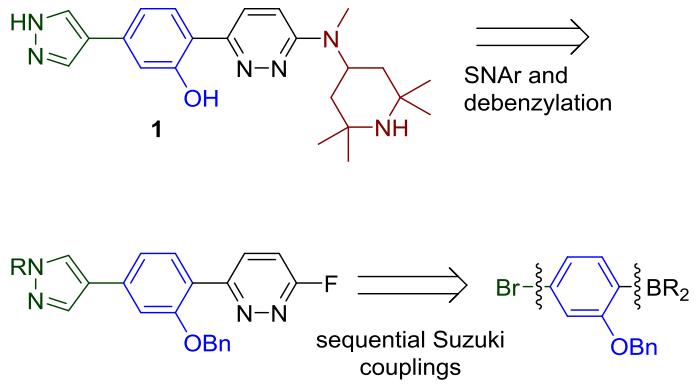

Our synthesis commenced with a palladium-catalyzed borylation $^{3}$ of iodide 2 that afforded a mixture (90:10) of boronates $\mathbf{3}$ and 3', which was directly used in a SuzukiMiyaura coupling with iodopyridazine $\mathbf{4}$ to furnish adduct $\mathbf{5}$ (Scheme 3). ${ }^{4}$ Initial attempts to perform this reaction using Fu's condition ${ }^{5,6}$ did not yield the expected adduct 5 (entry 1, Table 1). Switching to other catalytic systems using S-Phos, $\mathrm{X}$-Phos or $\mathrm{PPh}_{3}$ as ligands provided the desired adduct with a conversion of $20-32 \%$ (entries 2-4). Ultimately, the air and moisture stable $\mathrm{PdCl}_{2}$ (dppf) proved to be particularly effective (entry 5). Finally, several other combinations of solvent and base were examined, and when the reaction was carried out in dioxane $/ \mathrm{H}_{2} \mathrm{O}$ with the use of $\mathrm{K}_{3} \mathrm{PO}_{4}$ as a base, a $70 \%$ yield could be achieved (entry 8 ). This preference for $\mathrm{K}^{+}$as a counteraction of the base suggests that this Suzuki coupling involves a fast oxidation step and a rate-determining transmetalation. ${ }^{7}$

Further continuation of the synthesis required the replacement of the methoxy by a benzyloxy that can be efficiently deprotected in the final step. Indeed, Novartis scientists reported in their patent that the demethylation at a latter step is performed with a $13 \%$ yield only. ${ }^{2}$ Thus, demethylation with boron trichloride of $\mathbf{5}$, followed by benzylation, gave the requisite intermediate 7 in a $98 \%$ yield.

\section{Scheme 3. Synthesis of Intermediate 7}
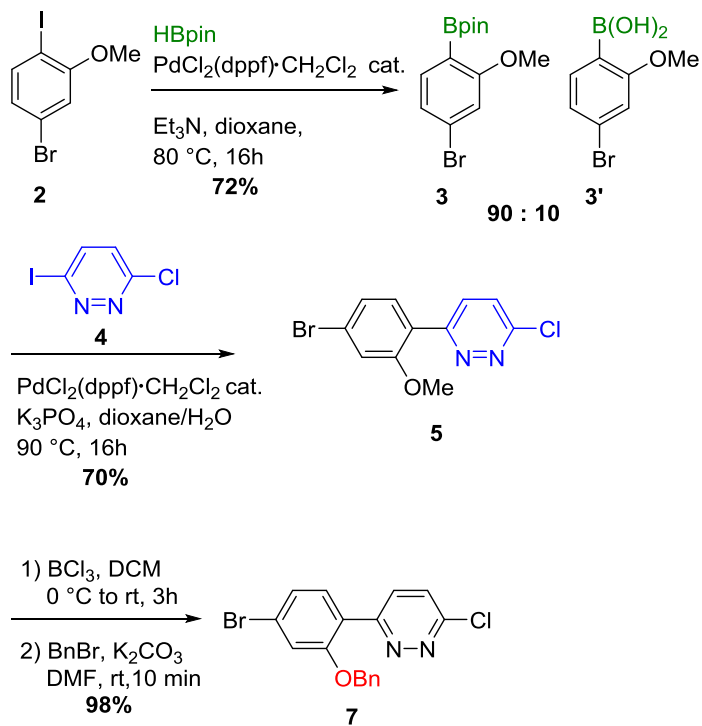

Table 1. Optimization of the First Suzuki-Miyaura Coupling

$$
\text { 3, 3' + } 4 \underset{\text { solvent, }{ }^{\circ} \mathrm{C}}{\stackrel{\text { cat., base }}{\longrightarrow}} \mathbf{5}
$$

\begin{tabular}{|c|c|c|c|c|c|}
\hline entry & cat. & base (eq) & solvent & $\mathrm{T}^{\circ} \mathrm{C}$ & $\begin{array}{l}\text { yield } \\
(\%)\end{array}$ \\
\hline 1 & $\begin{array}{c}\mathrm{Pd}_{2}(\mathrm{dba})_{3}(2 \mathrm{~mol} \%) \\
\mathrm{P}(t \mathrm{Bu})_{3}(3 \mathrm{~mol} \%)\end{array}$ & $\begin{array}{l}\mathrm{KF} \\
(3)\end{array}$ & $\mathrm{THF}$ & 80 & trace \\
\hline 2 & $\begin{array}{c}\mathrm{Pd}(\mathrm{OAc})_{2}(10 \mathrm{~mol} \%) \\
\text { S-Phos }(20 \mathrm{~mol} \%)\end{array}$ & $\begin{array}{c}\mathrm{K}_{2} \mathrm{CO}_{3} \\
(2.2)\end{array}$ & $\mathrm{ACN} / \mathrm{H}_{2} \mathrm{O}$ & 110 & 20 \\
\hline 3 & $\begin{array}{c}\mathrm{Pd}(\mathrm{OAc})_{2}(10 \mathrm{~mol} \%) \\
\mathrm{X}-\mathrm{Phos}(12 \mathrm{~mol} \%)\end{array}$ & $\begin{array}{c}\mathrm{K}_{3} \mathrm{PO}_{4} \\
\text { (2) }\end{array}$ & $n-\mathrm{BuOH} / \mathrm{H}_{2} \mathrm{O}$ & 110 & 21 \\
\hline 4 & $\mathrm{Pd}\left(\mathrm{PPh}_{3}\right)_{4}(5 \mathrm{~mol} \%)$ & $\begin{array}{l}\mathrm{Na}_{2} \mathrm{CO}_{3} \\
\text { (2) }\end{array}$ & $\begin{array}{c}\text { EtOH/toluene/ } \\
\mathrm{H}_{2} \mathrm{O}\end{array}$ & reflux & 32 \\
\hline 5 & $\begin{array}{c}\mathrm{PdCl}_{2}(\mathrm{dppf}) \cdot \mathrm{CH}_{2} \mathrm{Cl}_{2} \\
(10 \mathrm{~mol} \%)\end{array}$ & $\begin{array}{l}\mathrm{Na}_{2} \mathrm{CO}_{3} \\
\text { (2) }\end{array}$ & $\mathrm{DMF} / \mathrm{H}_{2} \mathrm{O}$ & 100 & 40 \\
\hline 6 & $\begin{array}{c}\mathrm{PdCl}_{2}(\mathrm{dppf}) \cdot \mathrm{CH}_{2} \mathrm{Cl}_{2} \\
(10 \mathrm{~mol} \%)\end{array}$ & $\begin{array}{c}\mathrm{CsF} \\
(0.5)\end{array}$ & $\mathrm{DMF} / \mathrm{H}_{2} \mathrm{O}$ & 100 & 17 \\
\hline 7 & $\begin{array}{c}\mathrm{PdCl}_{2}(\mathrm{dppf}) \cdot \mathrm{CH}_{2} \mathrm{Cl}_{2} \\
(10 \mathrm{~mol} \%)\end{array}$ & $\begin{array}{l}\mathrm{Na}_{2} \mathrm{CO}_{3} \\
\text { (2) }\end{array}$ & $\mathrm{THF} / \mathrm{ACN} / \mathrm{H}_{2} \mathrm{O}$ & 100 & 12 \\
\hline 8 & $\begin{array}{c}\mathrm{PdCl}_{2}(\mathrm{dppf}) \cdot \mathrm{CH}_{2} \mathrm{Cl}_{2} \\
(10 \mathrm{~mol} \%)\end{array}$ & $\begin{array}{c}\mathrm{K}_{3} \mathrm{PO}_{4} \\
(3)\end{array}$ & dioxane $/ \mathrm{H}_{2} \mathrm{O}$ & 90 & 70 \\
\hline
\end{tabular}

With the intermediate 7 in hand, we proceeded to its coupling with the pyrazolylboronate moiety. Original attempts to perform this reaction using a pyrazolylboronate protected with a Boc were not satisfactory, due to the lability of the Boc in the examined conditions. To circumvent this issue, we incorporated a Trityl protecting group onto the pyrazolylboronate. This reagent was conveniently prepared in 3 steps from pyrazole 8 (Scheme 4).

Scheme 4. Preparation of Tritylpyrazolylboronate 11

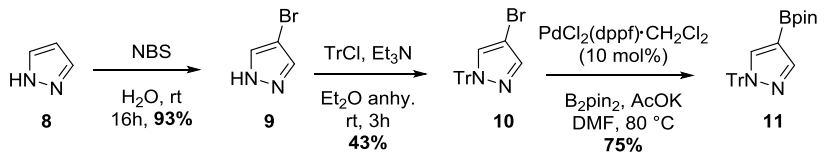

Table 2. Optimization of the Second Suzuki-Miyaura Coupling

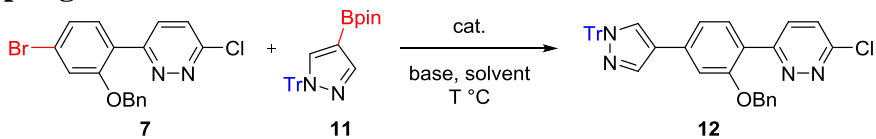

\begin{tabular}{|c|c|c|c|c|c|}
\hline entry & cat. & base (eq) & solvent & $\mathrm{T}^{\circ} \mathrm{C}$ & $\begin{array}{l}\text { yield } \\
(\%)\end{array}$ \\
\hline 1 & $\begin{array}{c}\mathrm{Pd}_{2}(\mathrm{dba})_{3}(3 \mathrm{~mol} \%) \\
\mathrm{P}(t \mathrm{Bu})_{3}(7 \mathrm{~mol} \%)\end{array}$ & $\begin{array}{l}\mathrm{KF} \\
(3.3)\end{array}$ & THF & 70 & 0 \\
\hline 2 & $\begin{array}{c}\mathrm{Pd}_{2}(\mathrm{dba})_{3}(1 \mathrm{~mol} \%) \\
\mathrm{PCy}_{3}(2.4 \mathrm{~mol} \%)\end{array}$ & $\begin{array}{c}\mathrm{K}_{3} \mathrm{PO}_{4} \\
(1.7)\end{array}$ & dioxane $/ \mathrm{H}_{2} \mathrm{O}$ & 100 & 0 \\
\hline 3 & $\begin{array}{l}\mathrm{Pd}\left(\mathrm{PPh}_{3}\right)_{4} \\
\left(10 \mathrm{~mol}^{2}\right)\end{array}$ & $\begin{array}{l}\mathrm{Na}_{2} \mathrm{CO}_{3} \\
\text { (2) }\end{array}$ & $\begin{array}{c}\mathrm{DME} / \mathrm{H}_{2} \mathrm{O} \\
(6 / 3)\end{array}$ & $\begin{array}{r}\text { MW } \\
150\end{array}$ & 28 \\
\hline 4 & $\begin{array}{l}\mathrm{Pd}\left(\mathrm{PPh}_{3}\right)_{4} \\
\left(10 \mathrm{~mol}^{2}\right)\end{array}$ & $\begin{array}{c}\mathrm{Na}_{2} \mathrm{CO}_{3} \\
(2)\end{array}$ & $\begin{array}{c}\mathrm{PhMe} / \mathrm{EtOH} / \mathrm{H}_{2} \mathrm{O} \\
(10 / 1 / 1)\end{array}$ & 110 & 30 \\
\hline
\end{tabular}


Table 3. Optimization of second Suzuki-Miyaura using 3bromoanisole 13 as a substrate

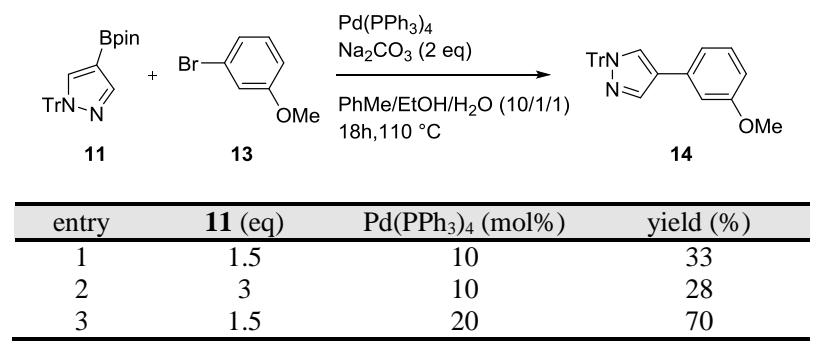

After extensive studies, we found that arylbromide 7 can be coupled in the presence of $\mathrm{Pd}\left(\mathrm{PPh}_{3}\right)_{4}$ with boronate 11 to prepare adduct 12 in a $30 \%$ yield (entries 3-4, Table 2). Initial attempts to use unprotected pyrazole-4-boronic acid did not deliver the expected adducts. When we examined this reaction with the reactant protected as a Boc, the yield was not reproducible and lied between 0 and $20 \%$.

To improve this reaction condition, we examined the coupling of 11 with 3-bromoanisole 13 using $\mathrm{Pd}\left(\mathrm{PPh}_{3}\right)_{4}, \mathrm{Na}_{2} \mathrm{CO}_{3}$ in $\mathrm{PhMe} / \mathrm{EtOH} / \mathrm{H}_{2} \mathrm{O} .{ }^{8}$ Our initial assay afforded the expected adduct in a $33 \%$ yield (entry 1 , Table 3 ). Increasing the amount of boronate $\mathbf{1 1}$ did not modify the yield (entry 2). Gratefully, doubling the amount of catalyst improved the yield up to $70 \%$ (entry 3 ), suggesting that the catalyst is unstable in this condition.

With an optimized Suzuki-Miyaura coupling of boronate $\mathbf{1 1}$ in hand, an efficient route to synthesize advanced intermediate 16 was developed (Scheme 5). First, the iminochloride 7 was treated with anhydrous tetramethylammonium fluoride under Sanford's condition ${ }^{9}$ to smoothly furnish fluoropyridazine $\mathbf{1 5}$, in $98 \%$ yield. The latter has two main advantages compared to the cognate chloropyridazine 7: the iminofluoride moiety is resistant to Suzuki coupling, and importantly, it is much more reactive in SNAr reactions. The coupling of boronate $\mathbf{1 1}$ with $\mathbf{1 5}$ delivered adduct $\mathbf{1 6}$ in $53 \%$ yield.

\section{Scheme 5. Synthesis of advanced intermediate}

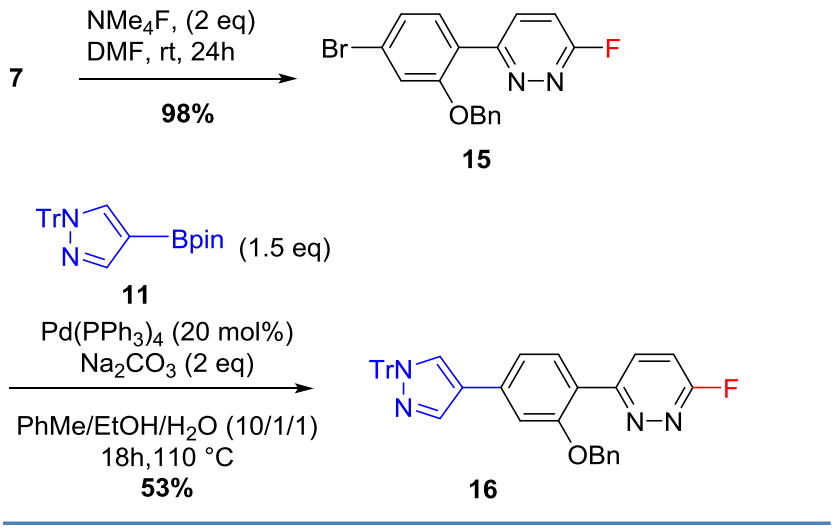

The synthesis of diamine $\mathbf{1 8}$ was conveniently achieved by formylation of $\mathbf{1 7}$ with ethyl formate and reduction of the obtained formamide with $\mathrm{LiAlH}_{4}$. Its condensation with fluoropyridazine $\mathbf{1 6}$ gave aminopyridazine $\mathbf{1 9}$ in a satisfactory yield $(56 \%)$ (Scheme 6). We originally considered performing this reaction with a chloropyridazine, but all of our attempts failed to deliver the expected adduct. Completion of the synthesis was accomplished by a double deprotection of the phenol and pyrazole moieties with a $94 \%$ yield for both steps.

\section{Scheme 6. Endgame of the Synthesis}
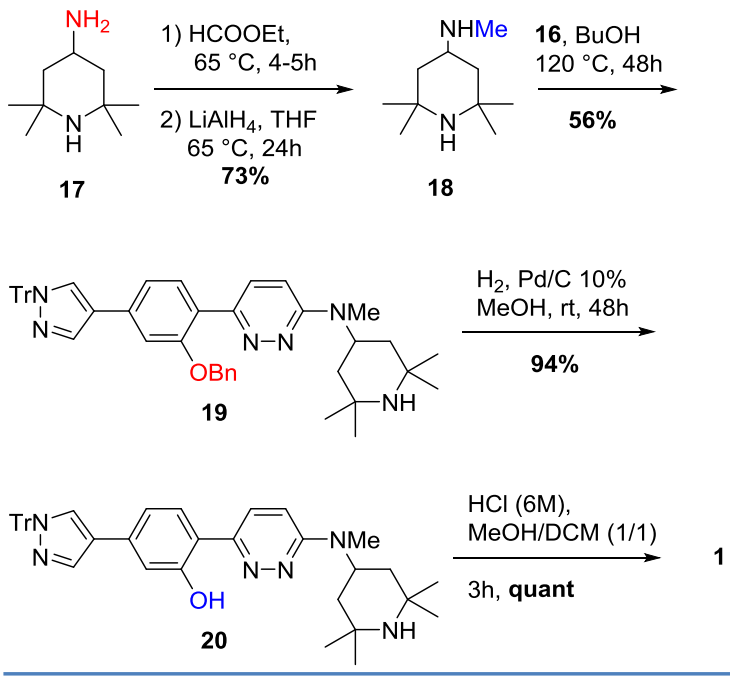

In conclusion, the synthesis of NVS-SM2 has been accomplished in 9 linear steps with an overall yield of 14\% (average yield: $82 \%$ ). It involves few more steps that the original one, however we optimized all the steps and some of them can be carried a very convenient manner with a near quantitative yield. For example, the conversion of 5 into 7 was performed in 2 steps with an overall yield of $98 \%$ and the intermediate of this sequence was directly used in the second step without purification. Actually, this sequence can be easily achieved in half a day. The fluoridation $(\mathbf{7} \rightarrow \mathbf{1 5})$ and deprotection $(\mathbf{1 9} \rightarrow$ $\mathbf{2 0} \rightarrow \mathbf{1})$ steps are also performed in high yield in a very expedient manner.

Thus, this route can satisfy the global demand for NVS-SM2 to examine in detail its therapeutic potential to treat SMA and other diseases associated with alterations in RNA splicing. In addition, the efficacy of the synthesis reported herein offers an opportunity to explore further the pharmacological effects of chemical modifications in the structure of NVS-SM2.

\section{EXPERIMENTAL SECTION}

All commercial reagents were used without purification. All the anhydrous solvents used are commercial or are conserved on molecular sieves. All reactions sensitive to moisture or oxygen were carried out under argon atmosphere and in flasks dried at $110{ }^{\circ} \mathrm{C}$. Reactions were stirred with a magnetic stirrer. Temperatures for the reactions refer to bath temperatures. Reactions were monitored by TLC $(0.2 \mathrm{~mm}$, Merck DC Platten Kieselgel $\left.60 \mathrm{~F}_{254}\right)$ with detection by UV light $(\lambda=254$ $\mathrm{nm})$ and treatment with anisaldehyde and potassium permanganate-stain. Melting points were recorded on an Electrothermal melting point apparatus and are uncorrected. 
NMR spectras were acquired on a Bruker DRX-400 spectrometer in $\mathrm{CDCl}_{3}$ (referenced to $7.26 \mathrm{ppm}$ for $1 \mathrm{H}$ and $77.0 \mathrm{ppm}$ for ${ }^{13} \mathrm{C}$ ), $\left(\mathrm{CD}_{3}\right)_{2} \mathrm{SO}$ (referenced to $2.50 \mathrm{ppm}$ for ${ }^{1} \mathrm{H}$ and $39.5 \mathrm{ppm}$ for ${ }^{13} \mathrm{C}$ ) or $\mathrm{CD}_{3} \mathrm{OD}$ (referenced to $3.31 \mathrm{ppm}$ for ${ }^{1} \mathrm{H}$ and $49 \mathrm{ppm}$ for ${ }^{13} \mathrm{C}$ ) as solvents. Coupling constants $(\mathrm{J})$ are in Hz. Chemical shifts are reported in parts per million ( $\mathrm{ppm})$. The multiplicities of the signals are described using the following abbreviations: $\mathrm{s}=$ singlet, $\mathrm{d}=$ doublet, $\mathrm{t}=$ triplet, $\mathrm{m}=$ multiplet. High resolution mass spectra were recorded on a Bruker MicroTOF-Q (ESI Q-TOF) spectrometer.

\section{3-(4-Bromo-2-methoxyphenyl)-6-chloropyridazine (5)}

1,1'-Bis(diphenylphosphinoferrocene)-palladium (II) dichloride $\mathrm{CH}_{2} \mathrm{Cl}_{2}$ complex $(574 \mathrm{mg}, 0.70 \mathrm{mmol})$ was added to a dioxane $(19 \mathrm{~mL}) / \mathrm{H}_{2} \mathrm{O}(1 \mathrm{~mL})$ solution of iodopyridazine 4 (1.86 g, $7.73 \mathrm{mmol})$, boronates $\left(3,3^{\prime}\right)(2.2 \mathrm{~g}, 7.03 \mathrm{mmol})$ and potassium phosphate $(4.48 \mathrm{~g}, 21.08 \mathrm{mmol})$ at room temperature under argon atmosphere (the flask was evacuated and refilled with argon five times before adding of $\mathrm{Pd}$ complex). The reaction was heated at $90{ }^{\circ} \mathrm{C}$ for $16 \mathrm{~h}$. After cooling to room temperature, the reaction mixture was diluted with EtOAc $(50 \mathrm{~mL})$, filtered through celite with copious washings, and then concentrated. The organic layer was washed with water, brine, dried over anhydrous $\mathrm{MgSO}_{4}$, filtered, concentrated and purified by column chromatography on silica gel using DCM $(100 \%)$ as eluent to give $5(1.63 \mathrm{~g}, 70 \%)$ as a white solid ; $\mathrm{mp}=133-136{ }^{\circ} \mathrm{C} ;{ }^{l} \mathrm{H} \mathrm{NMR}\left(400 \mathrm{MHz}, \mathrm{CDCl}_{3}\right) \delta$ $3.87(3 \mathrm{H}, \mathrm{s}), 7.16(1 \mathrm{H}, \mathrm{d}, J=1.4 \mathrm{~Hz}), 7.26(1 \mathrm{H}, \mathrm{dd}, J=1.4$, $8.3 \mathrm{~Hz}), 7.49(1 \mathrm{H}, \mathrm{d}, J=9 \mathrm{~Hz}), 7.84(1 \mathrm{H}, \mathrm{d}, J=8.3 \mathrm{~Hz}), 7.98$ $(1 \mathrm{H}, \mathrm{d}, J=9 \mathrm{~Hz}) ;{ }^{13} \mathrm{C} \mathrm{NMR}\left(100 \mathrm{MHz}, \mathrm{CDCl}_{3}\right) \delta 56.0,115.0$, 123.6, 124.6, 125.4, 127.2, 130.3, 132.2, 155.1, 157.1, 157.6 ; HRMS (ESI-TOF) m/z: $[\mathrm{M}+\mathrm{H}]^{+}$calcd for $\mathrm{C}_{11} \mathrm{H}_{9} \mathrm{BrClN}_{2} \mathrm{O}$ 298.9581 ; found 298.9571 .

\section{5-Bromo-2-(6-chloropyridazin-3-yl)phenol (6)}

To a stirred solution of 5 (500 $\mathrm{mg}, 1.67 \mathrm{mmol})$ in dry DCM $(50 \mathrm{~mL}), \mathrm{BCl}_{3}(5 \mathrm{~mL}, 5 \mathrm{mmol}, 1 \mathrm{M}$ in $\mathrm{DCM})$ was added dropwise at $0{ }^{\circ} \mathrm{C}$ under argon atmosphere. The resulting reaction mixture was stirred over $3 \mathrm{~h}$ at room temperature then quenched with water. The aqueous layer was extracted with DCM $(2 \times 50 \mathrm{~mL})$. Combined organic layers were washed with brine, dried over anhydrous $\mathrm{MgSO}_{4}$, filtered, and concentrated to give $6(470 \mathrm{mg}, 99 \%)$ as a pale-yellow solid which was used without further purification ; mp $=161-164{ }^{\circ} \mathrm{C} ;{ }^{l} \mathrm{H}$ NMR (400 MHz, $\left.\mathrm{CDCl}_{3}\right): \delta 7.10(1 \mathrm{H}, \mathrm{dd}, J=1.5,8.5 \mathrm{~Hz})$, $7.29(1 \mathrm{H}, \mathrm{d}, J=1.5 \mathrm{~Hz}), 7.52(1 \mathrm{H}, \mathrm{d}, J=8.5 \mathrm{~Hz}), 7.67(1 \mathrm{H}, \mathrm{d}$, $J=9.3 \mathrm{~Hz}), 8.01(1 \mathrm{H}, \mathrm{d}, J=9.3 \mathrm{~Hz}) ;{ }^{13} \mathrm{C} \mathrm{NMR}(100 \mathrm{MHz}$, $\left.\mathrm{CDCl}_{3}\right): \delta 114.9,122.4,122.9,125.7,127.1,127.5,130.1$, 155.0, 159.5, 160.5 ; HRMS (ESI-TOF) m/z: $[\mathrm{M}+\mathrm{H}]^{+}$calcd for $\mathrm{C}_{10} \mathrm{H}_{7} \mathrm{BrClN}_{2} \mathrm{O} 284.9425$; found 284.9420 .

\section{3-[2-(Benzyloxy)-4-bromophenyl]-6-chloropyridazine (7)}

To a stirred solution of phenol $6(130 \mathrm{mg}, 0.45 \mathrm{mmol})$ in dry DMF (1.5 mL), was added potassium carbonate $(126 \mathrm{mg}, 0.9$ $\mathrm{mmol})$ and then benzyl bromide $(86 \mathrm{mg}, 0.5 \mathrm{mmol})$ at room temperature under argon atmosphere. The resulting reaction mixture was stirred over $10 \mathrm{~min}$ at the same temperature and then diluted with DCM (15 mL). The organic layer was washed with water, dried over anhydrous $\mathrm{MgSO}_{4}$, filtered and concentrated to give chloropyridazine $7(167 \mathrm{mg}, 98 \%)$ as a white solid which was used without further purification ; $\mathrm{mp}=$
177-180 ${ }^{\circ} \mathrm{C} ;{ }^{l} \mathrm{H}$ NMR (400 MHz, $\left.\mathrm{CDCl}_{3}\right): \delta 5.12(2 \mathrm{H}, \mathrm{s})$, 7.27-741 (8H, m), $7.89(1 \mathrm{H}, \mathrm{d}, J=8.3 \mathrm{~Hz}), 7.98(1 \mathrm{H}, \mathrm{d}, J=9$ $\mathrm{Hz}) ;{ }^{13} \mathrm{C} \mathrm{NMR}\left(100 \mathrm{MHz}, \mathrm{CDCl}_{3}\right): \delta 71.4,116.6,124.1$, $125.1,125.4,127.2,127.5,128.6,128.9,130.4,132.5,135.6$, 155.2, 156.9, 157.1 ; HRMS (ESI-TOF) m/z: $[\mathrm{M}+\mathrm{H}]^{+}$calcd for $\mathrm{C}_{17} \mathrm{H}_{13} \mathrm{BrClN}_{2} \mathrm{O} 374.9894$; found 374.9883 .

\section{4-(4,4,5,5-Tetramethyl-1,3,2-dioxaborolan-2-yl)-1-trityl- $1 H$-pyrazole (11)}

To a stirred solution of 4-bromo-tritylpyrazole $\mathbf{1 0}$ (2 g, 5.14 $\mathrm{mmol}$ ) and bis(pinacolato)diboron (1.44 $\mathrm{g}, 5.65 \mathrm{mmol})$ in $\operatorname{DMF}(14 \mathrm{ml})$, was added 1,1'-bis(diphenylphosphinoferrocene)-palladium (II) dichloride $\mathrm{CH}_{2} \mathrm{Cl}_{2}$ complex (420 mg, $0.51 \mathrm{mmol})$ and potassium acetate $(1.51 \mathrm{~g}, 15.42 \mathrm{mmol})$ at room temperature under argon atmosphere. The resulting mixture was heated at $80{ }^{\circ} \mathrm{C}$ for $16 \mathrm{~h}$. After cooling to room temperature, the reaction mixture was diluted with DCM (50 $\mathrm{mL})$. The organic layer was washed with water, brine, dried over anhydrous $\mathrm{MgSO}_{4}$, filtered, concentrated and purified by column chromatography on silica gel using pentane / $\mathrm{Et}_{2} \mathrm{O}$ $(10 / 0$ to $8 / 2)$ as eluent to give boronate $11(1.8 \mathrm{~g}, 75 \%)$ as a white solid ; mp $=190-193{ }^{\circ} \mathrm{C} ;{ }^{l} \mathrm{H}$ NMR (400 MHz, $\left.\mathrm{CDCl}_{3}\right)$ : $\delta 1.33(12 \mathrm{H}, \mathrm{s}), 7.13-7.20(6 \mathrm{H}, \mathrm{d}, \mathrm{m}), 7.28-7.34(9 \mathrm{H}, \mathrm{d}, \mathrm{m})$, $7.79(1 \mathrm{H}, \mathrm{s}), 7.98(1 \mathrm{H}, \mathrm{s}) ;{ }^{13} \mathrm{C}$ NMR $\left(100 \mathrm{MHz}, \mathrm{CDCl}_{3}\right): \delta$ 24.9, 78.8, 83.4, 127.7, 127.8, 130.2, 138.8, 143.2, 145.9 ; HRMS (ESI-TOF) m/z: $[\mathrm{M}+\mathrm{Na}]^{+}$calcd for $\mathrm{C}_{28} \mathrm{H}_{29} \mathrm{BN}_{2} \mathrm{NaO}_{2}$ 459.2214 ; found 459.2210 .

\section{3-(2-(Benzyloxy)-4-(1-trityl-1H-pyrazol-4-yl)phenyl)-6- chloropyridazine (12)}

$\mathrm{Pd}\left(\mathrm{PPh}_{3}\right)_{4}(31 \mathrm{mg}, 0.027 \mathrm{mmol})$ was added to a stirred solution of chloropyridazine 7 (100 mg, $0.27 \mathrm{mmol})$, boronate 11 (174 $\mathrm{mg}, 0.40 \mathrm{mmol})$ and $\mathrm{Na}_{2} \mathrm{CO}_{3}(117 \mathrm{mg}, 0.53 \mathrm{mmol})$ in PhMe (3 $\mathrm{ml}) / \mathrm{EtOH}(0.3 \mathrm{ml}) / \mathrm{H}_{2} \mathrm{O}(0.3 \mathrm{ml})$ at room temperature under argon atmosphere (the flask was purged five times with argon before adding the $\mathrm{Pd}$ complex). The resultant mixture was stirred at the same temperature for $5 \mathrm{~min}$ and then at $110{ }^{\circ} \mathrm{C}$ for $18 \mathrm{~h}$. After cooling to room temperature, the reaction mixture was diluted with EtOAc $(25 \mathrm{~mL})$. The organic layer was washed with water, brine, dried over $\mathrm{MgSO}_{4}$, concentrated and purified by column chromatography on silica gel using pentane $/ \mathrm{Et}_{2} \mathrm{O}(8 / 2$ to $5 / 5)$ as eluent to give chloropyridazine 12 (50 mg, 30\%) as a white solid ; mp = 216-219 ${ }^{\circ} \mathrm{C} ;{ }^{l} \mathrm{H}$ NMR $\left(400 \mathrm{MHz}, \mathrm{CDCl}_{3}\right): \delta 5.07(2 \mathrm{H}, \mathrm{s}), 7.05(1 \mathrm{H}, \mathrm{d}, J=0.9 \mathrm{~Hz})$, 7.07-7.20 (8H, m), 7.21-7.35 (14H, m), $7.60(1 \mathrm{H}, \mathrm{s}), 7.88(1 \mathrm{H}$, s), $7.90(1 \mathrm{H}, \mathrm{d}, J=8 \mathrm{~Hz}), 7.96(1 \mathrm{H}, \mathrm{d}, J=9 \mathrm{~Hz}) ;{ }^{13} \mathrm{C} \mathrm{NMR}$ $\left(100 \mathrm{MHz}, \mathrm{CDCl}_{3}\right): \delta 71.1,79.1,110.2,119.1,121.0,123.0$, $127.0,127.5,127.9,128.0,128.3,128.8,129.6,130.2,130.5$, 131.7, 136.3, 137.4, 143.0, 154.7, 156.9, 157.6 ; HRMS (ESITOF) $\mathrm{m} / \mathrm{z}$ : $[\mathrm{M}+\mathrm{H}]^{+}$calcd for $\mathrm{C}_{39} \mathrm{H}_{30} \mathrm{ClN}_{4} \mathrm{O} 605.2103$; found 605.2108 .

\section{4-(3-Methoxyphenyl)-1-trityl-1H-pyrazole (14)}

The title compound was prepared similarly to the synthesis of chloropyridazine 12 starting from 3-bromoanisole $\mathbf{1 3}$ (80 mg, $0.054 \mathrm{mmol})$, boronate 11 (281 $\mathrm{mg}, 0.64 \mathrm{mmol})$, sodium carbonate $(91 \mathrm{mg}, 0.86 \mathrm{mmol}), \mathrm{Pd}\left(\mathrm{PPh}_{3}\right)_{4}(100 \mathrm{mg}, 0.086 \mathrm{mmol})$ and $\mathrm{PhMe}(3 \mathrm{ml}) / \mathrm{EtOH}(0.3 \mathrm{ml}) / \mathrm{H}_{2} \mathrm{O}(0.3 \mathrm{ml})$. The crude product was purified by chromatography on silica gel using pentane $/ \mathrm{Et}_{2} \mathrm{O}(10 / 0$ to $80 / 20)$ as eluent to give pyridazine 14 (126 mg, 70\%) as a white solid ; mp $=120-123{ }^{\circ} \mathrm{C} ;{ }^{l} \mathrm{H}$ NMR 
(400 MHz, $\left.\mathrm{CDCl}_{3}\right): \delta 3.82(3 \mathrm{H}, \mathrm{s}), 6.75(1 \mathrm{H}, \mathrm{ddd}, J=1.0,2.6$, $8.4 \mathrm{~Hz}), 7.96(1 \mathrm{H}, \mathrm{dd}, J=1.4,2.6 \mathrm{~Hz}), 7.03(1 \mathrm{H}, \mathrm{ddd}, J=1$, 1.4, 7.7 Hz), 7.20-7.25 (7H, m), 7.30-7.35 (9H, m), 7.61 (1H, $\mathrm{d}, J=0.8 \mathrm{~Hz}), 7.93(1 \mathrm{H}, \mathrm{d}, J=0.8 \mathrm{~Hz}) ;{ }^{13} \mathrm{C} \mathrm{NMR}(100 \mathrm{MHz}$, $\left.\mathrm{CDCl}_{3}\right): \delta 55.3,78.9,111.4,111.6,118.2,121.5,127.8,127.9$, 129.3, 129.8, 130.2, 134.0, 137.3, 143.1, 160.0 ; HRMS (ESITOF) $\mathrm{m} / \mathrm{z}$ : $[\mathrm{M}+\mathrm{Na}]^{+}$calcd for $\mathrm{C}_{29} \mathrm{H}_{24} \mathrm{~N}_{2} \mathrm{NaO} 439,1786$; found 439,1768 .

\section{3-[2-(Benzyloxy)-4-bromophenyl]-6-fluoropyridazine (15)}

To a stirred solution of chloropyridazine 7 (750 $\mathrm{mg}, 1.99$ mmol) in dry DMF (12 mL), anhydrous $\mathrm{NMe}_{4} \mathrm{~F}$ (375 mg, 3.98 mmol) was added at room temperature under argon atmosphere. The resulting reaction mixture was stirred at the same temperature for $24 \mathrm{~h}$ before it was diluted with DCM $(70 \mathrm{~mL})$. The organic layer was washed with water $(3 \times 120 \mathrm{~mL})$, brine $(1 \times 100 \mathrm{~mL})$, dried over anhydrous $\mathrm{MgSO}_{4}$, filtered and concentrated to give fluoropyridazine $\mathbf{1 5}(700 \mathrm{mg}, 98 \%)$ as a white solid which was used without further purification ; $\mathrm{mp}=$ 167-170 ${ }^{\circ} \mathrm{C} ;{ }^{l} \mathrm{H}$ NMR (400 MHz, $\mathrm{CDCl}_{3}$ ): $\delta 5.12(2 \mathrm{H}, \mathrm{s}), 7.13$ $(1 \mathrm{H}, \mathrm{dd}, J=1.5,9.2 \mathrm{~Hz}), 7.27-7.40(7 \mathrm{H}, \mathrm{m}), 7.8(1 \mathrm{H}, \mathrm{d}, J=8.2$ $\mathrm{Hz}), 8.12(1 \mathrm{H}, \mathrm{dd}, J=7.5,8.2 \mathrm{~Hz}) ;{ }^{13} \mathrm{C} \mathrm{NMR}(100 \mathrm{MHz}$, $\left.\mathrm{CDCl}_{3}\right): \delta 71.3,114.7(\mathrm{~d}, J=33 \mathrm{~Hz}), 116.5,124.2,125.1$, 125.2, 127.5, 128.6, 128.9, 132.5, 133.7 (d, $J=7 \mathrm{~Hz}), 135.6$, 156.7, $157.6(\mathrm{~d}, J=2.7 \mathrm{~Hz}), 165.7(\mathrm{~d}, J=245 \mathrm{~Hz}) ;{ }^{19} \mathrm{~F} \mathrm{NMR}$ decoupled ${ }^{1} \mathrm{H}\left(376 \mathrm{MHz}, \mathrm{CDCl}_{3}\right)$ : -81.27 (1F, s) ; ${ }^{19} \mathrm{~F}$ NMR coupled ${ }^{1} \mathrm{H}\left(376 \mathrm{MHz}, \mathrm{CDCl}_{3}\right)$ : $-81.27(1 \mathrm{~F}, \mathrm{~d}, J=7.5 \mathrm{~Hz})$; HRMS (ESI-TOF) $\mathrm{m} / \mathrm{z}$ : $[\mathrm{M}+\mathrm{H}]^{+}$calcd for $\mathrm{C}_{17} \mathrm{H}_{13} \mathrm{BrFN}_{2} \mathrm{O}$ 359.0190 ; found 359.0192 .

\section{3-[2-(Benzyloxy)-4-(1-trityl-1H-pyrazol-4-yl)phenyl]-6- fluoropyridazine (16)}

The title compound was prepared similarly to the synthesis of chloropyridazine 12 starting from fluoropyridazine 15 (200 $\mathrm{mg}, 0.55 \mathrm{mmol})$, boronate 11 (364 $\mathrm{mg}, 0.83 \mathrm{mmol})$, sodium carbonate $(117 \mathrm{mg}, 1.1 \mathrm{mmol}), \mathrm{Pd}\left(\mathrm{PPh}_{3}\right)_{4}(129 \mathrm{mg}, 0.11$ $\mathrm{mmol})$ and $\mathrm{PhMe}(5 \mathrm{ml}) / \mathrm{EtOH}(0.5 \mathrm{ml}) / \mathrm{H}_{2} \mathrm{O}(0.5 \mathrm{ml})$. The crude product was purified by chromatography on silica gel using pentane / $\mathrm{Et}_{2} \mathrm{O}(8 / 2$ to 5/5) as eluent to give fluoropyridazine $16(172 \mathrm{mg}, 53 \%)$ as a white solid ; $\mathrm{mp}=$ 203-206 ${ }^{\circ} \mathrm{C} ;{ }^{l} \mathrm{H}$ NMR (400 MHz, $\left.\mathrm{CDCl}_{3}\right): \delta 5.19(2 \mathrm{H}, \mathrm{s}), 7.13$ $(1 \mathrm{H}, \mathrm{dd}, J=1.5,9.2 \mathrm{~Hz}), 7.18(7 \mathrm{H}, \mathrm{d}, J=1.5 \mathrm{~Hz}), 7.22(1 \mathrm{H}$, $\mathrm{d}, J=8.3 \mathrm{~Hz}), 7.24-7.3(6 \mathrm{H}, \mathrm{m}), 7.32-7.43(14 \mathrm{H}, \mathrm{m}), 7.73$ $(1 \mathrm{H}, \mathrm{s}), 7.99(1 \mathrm{H}, \mathrm{dd}, J=1.4,8.2 \mathrm{~Hz}), 8.00(1 \mathrm{H}, \mathrm{s}), 8.21(1 \mathrm{H}$, $\mathrm{dd}, J=7.5,8.3 \mathrm{~Hz}) ;{ }^{13} \mathrm{C} \mathrm{NMR}\left(100 \mathrm{MHz}, \mathrm{CDCl}_{3}\right): \delta 71.1$, $79.1,110.2,114.5(\mathrm{~d}, J=33 \mathrm{~Hz}), 119.1,121.0,123.1,127.4$, $127.9,128.0,128.3,128.7,129.5,130.2,131.8,133.6(\mathrm{~d}, J=$ $6.8 \mathrm{~Hz}), 136.1,132.3,137.5,143.0,156.6,158.1(\mathrm{~d}, J=2.5$ $\mathrm{Hz}), 165(\mathrm{~d}, J=244 \mathrm{~Hz}) ;{ }^{19} \mathrm{~F}$ NMR decoupled ${ }^{1} \mathrm{H}(376 \mathrm{MHz}$, $\left.\mathrm{CDCl}_{3}\right)$ : -81.99; ${ }^{19} \mathrm{~F}$ NMR coupled ${ }^{1} \mathrm{H}\left(376 \mathrm{MHz}, \mathrm{CDCl}_{3}\right)$ : $81.99\left(\mathrm{dd}, J=1.4,7.5 \mathrm{~Hz}\right.$ ) ; HRMS (ESI-TOF) m/z: $[\mathrm{M}+\mathrm{H}]^{+}$ calcd for $\mathrm{C}_{39} \mathrm{H}_{29} \mathrm{FN}_{4} \mathrm{O} 589.2398$; found 589.2395.

\section{$N, 2,2,6,6$-pentamethylpiperidin-4-amine (18)}

A solution of $17(4.4 \mathrm{~mL}, 0.026 \mathrm{mmol})$ in ethyl formate $(6.5$ $\mathrm{mL}, 0.078 \mathrm{mmol}$ ) was heated at $65^{\circ} \mathrm{C}$ for $4-5 \mathrm{~h}$. The resulting thick, white suspension was cooled to room temperature and filtered. After the filter cake was washed with EtOAc $(20 \mathrm{~mL})$, the solid was dried under vacuum to give $3.8 \mathrm{~g}$ (79 \% yield) of $\mathrm{N}$-(2,2,6,6-tetramethylpiperidin-4-yl)formamide, which was used directly in the next step. A $250 \mathrm{~mL}$ round bottom flask equipped with a large Teflon-coated stir bar was charged with $\mathrm{LiAlH}_{4}(1.17 \mathrm{~g}, 31 \mathrm{mmol})$, fitted with a reflux condenser, and purged with argon. THF $(40 \mathrm{~mL})$ was added and the resulting suspension was cooled to $0 \quad{ }^{\circ} \mathrm{C}$. A $N-(2,2,6,6-$ tetramethylpiperidin-4-yl)formamide (3.8 g, $20.6 \mathrm{mmol})$ was added in portion over $10 \mathrm{~min}$ (CAUTION: hydrogen gas evolution!). The cooling bath was replaced with an oil bath and the colorless solution was heated at $65{ }^{\circ} \mathrm{C}$ for $24 \mathrm{~h}$ under a slow stream of argon. The resulting white suspension was cooled to $0{ }^{\circ} \mathrm{C}$ and then carefully quenched by dropwise addition of water $(10 \mathrm{~mL}$; CAUTION: violently exothermic reaction, evolution of hydrogen gas!) followed by a $20 \%$ aq $\mathrm{NaOH}$ solution $(20 \mathrm{~mL})$. The resulting suspension was stirred at room temperature for $15 \mathrm{~min}$. $\mathrm{MeOH}(40 \mathrm{~mL})$ was added then the mixture was filtered on celite. The filtrate was concentrated and then the residue was dissolved with EtOAc $(50 \mathrm{~mL})$. The organic layer was washed with water, brine, dried over anhydrous $\mathrm{MgSO}_{4}$, filtered and concentrated to give diamine 18 $(3.25 \mathrm{~g}, 93 \%)$ as a yellow liquid which was used without further purification ; ${ }^{l} \mathrm{H}$ NMR $\left(400 \mathrm{MHz},\left(\mathrm{CD}_{3}\right)_{2} \mathrm{SO}\right): \delta 0.72(2 \mathrm{H}$, $\mathrm{t}, J=11.8 \mathrm{~Hz}), 1.00(6 \mathrm{H}, \mathrm{s}), 1.09(6 \mathrm{H}, \mathrm{s}), 1.68(2 \mathrm{H}, \mathrm{dd}, J=$ $3.4,12.3 \mathrm{~Hz}), 2.26(3 \mathrm{H}, \mathrm{s}), 2.6(1 \mathrm{H}, \mathrm{tdd}, J=3.5,11.5,11.5$ $\mathrm{Hz}) ;{ }^{13} \mathrm{C} \mathrm{NMR}\left(100 \mathrm{MHz},\left(\mathrm{CD}_{3}\right)_{2} \mathrm{SO}\right): \delta 28.5,32.5,34.3$, 44.5, 49.7, 50.6 ; HRMS (ESI-TOF) m/z: $[\mathrm{M}+\mathrm{H}]^{+}$calcd for $\mathrm{C}_{10} \mathrm{H}_{23} \mathrm{~N}_{2}$ 171.1856; found 171.1853.

\section{6-[2-(Benzyloxy)-4-(1-trityl-1H-pyrazol-4-yl)phenyl]- $N$ - methyl- $N$-(2,2,6,6-tetramethylpiperidin-4-yl)pyridazin-3- amine (19)}

To a stirred solution of $\mathbf{1 6}(230 \mathrm{mg}, 0.39 \mathrm{mmol})$ in butan-1-ol (4 ml), diamine 18 (133 mg, $0.78 \mathrm{mmol})$ was added at room temperature under argon atmosphere. The mixture was heated at $120{ }^{\circ} \mathrm{C}$ for $48 \mathrm{~h}$. After cooling to room temperature, butan-1ol was removed using rotary evaporator, then the residue was diluted with DCM $(50 \mathrm{~mL})$. The organic layer was washed with water, dried over anhydrous $\mathrm{MgSO}_{4}$, filtered, concentrated and purified by flash chromatography on silica gel using DCM / MeOH (10/0 to 8/2) as eluent to give 19 (160 mg, $56 \%)$ as a yellow solid ; mp $=105-108{ }^{\circ} \mathrm{C} ;{ }^{l} \mathrm{H}$ NMR $(400$ $\left.\mathrm{MHz}, \mathrm{CDCl}_{3}\right): \delta 1.18(6 \mathrm{H}, \mathrm{s}), 1.35(6 \mathrm{H}, \mathrm{s}), 1.38(2 \mathrm{H}, \mathrm{m}), 1.70$ $(2 \mathrm{H}, \mathrm{dd}, J=2.1,12 \mathrm{~Hz}), 2.96(3 \mathrm{H}, \mathrm{s}), 5.13(2 \mathrm{H}, \mathrm{s}), 5.15(1 \mathrm{H}$, m), $6.72(1 \mathrm{H}, \mathrm{d}, J=9.7 \mathrm{~Hz}), 7.07(1 \mathrm{H}, \mathrm{d}, J=1.3 \mathrm{~Hz}), 7.14$ $(1 \mathrm{H}, \mathrm{dd}, J=1.3,8 \mathrm{~Hz}), 7.17-7.25(6 \mathrm{H}, \mathrm{m}), 7.28-7.4(14 \mathrm{H}, \mathrm{m})$, $7.63(1 \mathrm{H}, \mathrm{s}), 7.84(1 \mathrm{H}, \mathrm{d}, J=9.5 \mathrm{~Hz}), 7.92(1 \mathrm{H}, \mathrm{s}), 7.98(1 \mathrm{H}, \mathrm{d}$, $J=8 \mathrm{~Hz}) ;{ }^{13} \mathrm{C}$ NMR $\left(100 \mathrm{MHz}, \mathrm{CDCl}_{3}\right): \delta 28.8,29.2,35.3$, 41.9, 47.5, 51.5, 71.0, 79.0, 110.4, 119.0, 121.4, 125.3, 127.3, $127.8,127.9,128.6,129.2,129.4,130.2,130.9,134.1,137.0$, 137.4, 143.1, 149.1, 156.3, 158.2 ; HRMS (ESI-TOF) m/z: $[\mathrm{M}+\mathrm{H}]^{+}$calcd for $\mathrm{C}_{49} \mathrm{H}_{51} \mathrm{~N}_{6} \mathrm{O} 739.4119$; found 739.4138 .

\section{2-[6-[Methyl(2,2,6,6-tetramethylpiperidin-4- yl)amino]pyridazin-3-yl]-5-(1-trityl-1H-pyrazol-4- yl)phenol (20)}

To a stirred solution of $\mathbf{1 9}(110 \mathrm{mg}, 0.15 \mathrm{mmol})$ in $\mathrm{MeOH}$ (7 $\mathrm{ml}$ ), catalytic amount of $10 \%$ palladium on carbon was added under $\mathrm{H}_{2}$ atmosphere. The mixture was stirred for $48 \mathrm{~h}$ at room temperature and then filtered on celite. The filtrate was concentrated and purified by flash chromatography on silica gel using DCM / MeOH (10/0 to 8/2) as eluent to give phenol 20 (90 mg, 94\%) as a yellow solid ; $\mathrm{mp}=132-135{ }^{\circ} \mathrm{C} ;{ }^{l} \mathrm{H}$ NMR (400 MHz, $\left.\mathrm{CDCl}_{3}\right): \delta 1.18(6 \mathrm{H}, \mathrm{s}), 1.35(6 \mathrm{H}, \mathrm{s}), 1.40(2 \mathrm{H}, \mathrm{t}, J$ $=12.3 \mathrm{~Hz}), 1.69(2 \mathrm{H}, \mathrm{dd}, J=2,12 \mathrm{~Hz}), 3.00(3 \mathrm{H}, \mathrm{s}), 4.88(1 \mathrm{H}$, 
m), $6.98(1 \mathrm{H}, \mathrm{d}, J=9.8 \mathrm{~Hz}), 7.01(1 \mathrm{H}, \mathrm{d}, J=8.1 \mathrm{~Hz}), 7.11$ $(1 \mathrm{H}, \mathrm{s}), 7.16-7.23(6 \mathrm{H}, \mathrm{m}), 7.29-7.37(9 \mathrm{H}, \mathrm{m}), 7.52(1 \mathrm{H}, \mathrm{d}, J=$ $8.3 \mathrm{~Hz}), 7.66(1 \mathrm{H}, \mathrm{s}), 7.92(1 \mathrm{H}, \mathrm{s}), 7.79(1 \mathrm{H}, \mathrm{d}, J=9.8 \mathrm{~Hz})$, $7.98(1 \mathrm{H}, \mathrm{s}) ;{ }^{13} \mathrm{C}$ NMR $\left(100 \mathrm{MHz}, \mathrm{CDCl}_{3}\right): \delta 28.9,29.4,35.3$, $42.0,48.4,51.5,79.1,113.9,114.8,116.0,116.8,121.2$, $124.5,125.4,128.0,129.7,130.3,134.8,137.5,143.2,151.6$, 157.9, 159.4 ; HRMS (ESI-TOF) $\mathrm{m} / \mathrm{z}:[\mathrm{M}+\mathrm{H}]^{+}$calcd for $\mathrm{C}_{42} \mathrm{H}_{45} \mathrm{~N}_{6} \mathrm{O} 649.3649$; found 649.3634 .

2-[6-[Methyl(2,2,6,6-tetramethylpiperidin-4yl)amino]pyridazin-3-yl]-5-(1H-pyrazol-4-yl)phenol (1)

To a stirred solution of $\mathbf{2 0}(80 \mathrm{mg}, 0.12 \mathrm{mmol})$ in THF (2 ml) / $\mathrm{MeOH}(2 \mathrm{ml}), 2 \mathrm{ml}$ of $\mathrm{HCl}(6 \mathrm{M})$ was added at room temperature. The mixture was stirred at the same temperature. After $3 \mathrm{~h}$, solvents were removed using rotary evaporator. The yellow product obtained in salt form was dissolved in DCM / $\mathrm{MeOH}$ (50/50) and neutralized with addition of solid $\mathrm{NaHCO}_{3}$. Then the mixture was filtered through celite. The filtrate was concentrated and purified by flash chromatography using DCM / MeOH (10/0 to 8/2) as eluent to give NVS-SM2 (1) (48 mg, quant.) as a yellow solid ; mp $=146-149{ }^{\circ} \mathrm{C} ;{ }^{l} \mathrm{H}$ NMR (400 MHz, MeOD): $\delta 1.22$ (6H, s), 1.35 (6H, s), 1.48$1.65(4 \mathrm{H}, \mathrm{m}), 2.87(3 \mathrm{H}, \mathrm{s}), 4.98(1 \mathrm{H}, \mathrm{m}), 7.04-7.17(3 \mathrm{H}, \mathrm{m})$, $7.59(1 \mathrm{H}, \mathrm{d}, J=7.4 \mathrm{~Hz}), 7.89(1 \mathrm{H}, \mathrm{d}, J=9.4 \mathrm{~Hz}), 7.97(2 \mathrm{H}, \mathrm{s})$ $;{ }^{13} \mathrm{C}$ NMR (100 MHz, MeOD): $\delta$ 27.5, 29.8, 33.6, 41.3, 54, $115,116.3,117.2,117.6,123,126.4,127.3,136.2,152.8$, 159.2, 159.9 ; HRMS (ESI-TOF) $\mathrm{m} / \mathrm{z}:[\mathrm{M}+\mathrm{H}]^{+}$calcd for $\mathrm{C}_{23} \mathrm{H}_{31} \mathrm{~N}_{6} \mathrm{O} 407.2554$; found 407.2550.

\section{ASSOCIATED CONTENT}

\section{Supporting Information}

The Supporting Information is available free of charge on the ACS Publications website at DOI:

Spectral data for compounds described herein (PDF)

\section{AUTHOR INFORMATION}

\section{Corresponding Author}

*E-mail: desaubry@unistra.fr

\section{Present Address}

Laboratory of Therapeutic Innovation (UMR 7200), Faculty of Pharmacy, University of Strasbourg-CNRS, 67401, Illkirch, France

Notes

The authors declare no competing financial interest.

\section{ACKNOWLEDGMENTS}

We thank the "Ministère de l'Enseignement Supérieur et de l'Innovation" for a fellowship to $\mathrm{H}$. A-H.

\section{REFERENCES}

(1) Palacino, J.; Swalley, S. E.; Song, C.; Cheung, A. K.; Shu, L.; Zhang, X.; Van Hoosear, M.; Shin, Y.; Chin, D. N.; Keller, C. G.; Beibel, M.; Renaud, N. A.; Smith, T. M.; Salcius, M.; Shi, X.; Hild, M.; Servais, R.; Jain, M.; Deng, L.; Bullock, C.; McLellan, M.; Schuierer, S.; Murphy, L.; Blommers, M. J.; Blaustein, C.; Berenshteyn, F.; Lacoste, A.; Thomas, J. R.; Roma, G.; Michaud, G. A.; Tseng, B. S.; Porter, J. A.; Myer, V. E.; Tallarico, J. A.; Hamann, L. G.; Curtis, D.; Fishman, M. C.; Dietrich, W. F.; Dales, N. A.; Sivasankaran, R. Nat. Chem. Biol. 2015, 11, 511-517.

(2) Cheung, A.; Chin, D. N.; Dales, N.; Fazal, A.; Hurley, T. B.; Kerrigan, J.; O'Brien, G.; Shu, L.; Sun, R.; Sung, M., WO2014028459A1.

(3) Murata, M.; Watanabe, S.; Masuda, Y., J. Org. Chem. 1997, 62, 6458-6459.

(4) We considered starting our synthesis with a reagent protected by a benzyl, but the borylation step (similar to $\mathbf{2} \rightarrow \mathbf{3}+\mathbf{3}$ ') did not afford the expected compound.

(5) Kudo, N.; Perseghini, M.; Fu, G. C. Angew. Chem., Int. Ed. Engl. 2006, $45,1282-1284$.

(6) Littke, A. F.; Dai, C.; Fu, G. C. J. Am. Chem. Soc. 2000, 122, 4020-4028.

(7) Amatore, C.; Jutand, A.; Le Duc, G. Chem. - Eur. J. 2012, 18, 6616-6625.

(8) Aryl bromides have been shown to afford higher yield that the cognate triflates on this type of substrates: Yang, Y.; Oldenhuis N. J.; Buchwald, S. L. Angew. Chem., Int. Ed. Engl. 2013, 52, 615-619.

(9) Schimler, S. D.; Ryan, S. J.; Bland, D. C.; Anderson, J. E.; Sanford, M. S., J. Org. Chem. 2015, 80, 12137-121. 